\title{
Effect of Seed Bio-priming with Microbial Inoculants on Plant Growth, Yield and Yield Contributing Characters in Soybean [Glycine max (L.) Merril]
}

\author{
Pramod Sharma*, Arun Bhatt and Bhim Jyoti
}

College of Forestry, VCSG Uttarakhand University of Horticulture and Forestry, Bharsar, Uttarakhand (249 199), India

\section{Corresponding Author}

Pramod Sharma

e-mail: sharmapramod827@gmail.com

\author{
Article History \\ Article ID: IJEP0214 \\ Received in $23^{\text {rd }}$ January, 2018 \\ Received in revised form $14^{\text {th }}$ February, 2018 \\ Accepted in final form $10^{\text {th }}$ March, 2018
}

\begin{abstract}
The present investigation was carried out to study the effect of seed bio-priming with microbial inoculants on plant growth, yield and yield contributing characters in soybean [Glycine max (L.) Merril] at Research Station, Gaja and Department of Seed Science and Technology, College of Forestry, Ranichauri, Tehri Garhwal, Uttarakhand, India during kharif season 2014. All the factors in experiment as well as their interactions showed significant influence on plant growth, yield and yield contributing characters in soybean. Among all the treatments, highest field emergence (88.47\%) and minimum days to $50 \%$ flowering ( 40.75 days) was recorded in Psf-173 while maximum plant height $(30.34 \mathrm{~cm}$ ) was measured in Th-14. However, seed yield and other contributing characters were improved by PSB bio-primed seed. Among different varieties, Shilajeet variety showed greater value in field emergence $(89.27 \%)$, plant height $\left(34.25 \mathrm{~cm}^{2}\right.$, number of branches plant ${ }^{-1}$ (4.46), number of pods plant ${ }^{-1}(31.18)$, pod length $(3.39 \mathrm{~cm})$, number of seeds pod ${ }^{-1}(2.71)$, number of nodule plant ${ }^{-1}(30.68)$ and seed yield plant $^{-1}$ (17.03 g). However, earliest days to 50\% flowering (39.13 days) was recorded in PS 1092 variety. On the basis of field experiment, PSB proved to be the best bio-agent for enhancing the growth than other tested bio-agents and in respect of selected varieties for priming purpose, Shilajeet was found most promising. The interaction between PSB and Shilajeet also had good combination for above mentioned characters. The present study thus reveals that seed bio-priming enhances growth and yield parameters in soybean. It is therefore suggested that before sowing, soybean seed should be treated with PSB and Psf-173 bio-agents.
\end{abstract}

Keywords: Biopriming, PSB, Pseudomonas fluorescens, Trichoderma harzianum, Soybean

\section{Introduction}

Soybean is known as world's most important crop due to its high protein and oil content (Raei et al., 2008). Soybean crop is most important source of vegetable oil in India that occupies $35-65 \%$ of total oilseed crop in country. The world production of edible oils consists of $30 \%$ soybean. Among the grain legumes, it has the greatest potential of producing the cheapest source of food protein (Rao and Reddy, 2010). Due to high protein content, soybean is known as "poor man's meat". Soybean represents half of the global legume crop area and $68 \%$ of global production and fixes $16.4 \mathrm{Tg} \mathrm{N}$ year $^{-1}$, it represents more than three fourth of the $\mathrm{N}$ fixed by the legume crops (Herridge et al., 2008).

Seed treatment with bio-control agents along with priming agents may serve as an important means of managing many soil and seed-borne diseases and promote growth of plant, the process known as "bio-priming". Biological agents such as beneficial fungi and bacteria are used in bio-priming which includes fungi and antagonistic bacteria and the most important of all are Trichoderma and Pseudomonas.
Bio-priming treatment is potentially prominent to induce profound changes in plant characteristics and to encourage more uniform seed germination and plant growth associated with fungi and bacteria coatings (Entesari et al., 2013).

In order to improve the yield and disease suppression, most of the farmers resort to inorganic fertilizers and possibly pesticides which have harmful effects on human beings as well as animals. An alternative approach of chemical pesticides is the use of bio-control agents for plant disease management. Among various mode of application of bio-control agents, seed bio-priming has been found very effective mode to augment plant health through enhanced rate of germination, nodule numbers and uptake of inorganic phosphates in soybean.

Phosphorous solubilizing bacteria (PSB) have been found useful in enhancing phosphorous availability to plant through solubilization, converting low grade rock phosphate into available form of phosphorous to plant and increasing the seed yield. Pseudomonas fluorescens belonging to plant growth promoting rhizobacteria (PGPR) is known to enhance plant growth and reduce severity of many fungal diseases by the suppressing deleterious rhizosphere microorganisms 
on the root. Trichoderma harzianum is a worldwide soil borne anamorphic fungus. Trichoderma spp. have potential as biological control agents against many plant pathogens. Trichoderma spp. are considered as potential bio-control and growth promoting agents for many crop plants (Savazzini et al., 2009).

In the era of sustainable agricultural production, the beneficial plant microbe interaction in the rhizosphere play a vital role in transformation, mobilization, solubilization etc. from a limited nutrient pool in soil and subsequent uptake of essential plant nutrients by the crop plant to utilize full genetic potential of the crop. As the seed treatment campaign is gaining momentum, new eco-friendly alternatives for seed treatment need to be searched out for managing the seed borne pathogens through bio-priming separately or in combination. Thus, there is need to enhance the efficiency or major amount of external input by employing the best combination of beneficial microorganisms by priming seed for increasing the planting value, germination, uptake of inorganic phosphate, plant growth, seed yield and its subsequent quality. The objective of this study was to assess the influence of seed bio-priming on plant growth, seed yield and its contributing characters.

\section{Materials and Methods}

\subsection{Experimental material}

The experimental material consists of four varieties of soybean namely Shilajeet $\left(\mathrm{V}_{1}\right)$, PK 327 (V2), PS 1092 (V3) and PRS1 (V and five treatments consisting of three microbial inoculants i.e. phosphorous solubilizing bacteria (PSB) $\left(T_{1}\right)$, Pseudomonas fluorescens (Psf-173) $\left(T_{2}\right)$, Trichoderma harzianum (Th-14) $\left(T_{3}\right)$ and a combination of Pseudomonas fluorescens (Pf-173) and Trichoderma harzianum (Th-14) $\left(\mathrm{T}_{4}\right)$ along with uninoculated control $\left(\mathrm{T}_{5}\right)$.

\subsection{Seed bio-priming}

Before sowing, seeds were surface sterilized with $1 \%$ sodium hypochlorite solution for $3 \mathrm{~min}$, rinsed with sterilized water and air dried. For bio-priming, seeds were separately treated with talc formulation of different bio-agent viz. phosphorous solubilizing bacteria (PSB), Pseudomonas fluorescens (Pf-173), Trichoderma harzianum (Th-14) at the recommended dose of $8 \mathrm{~g} \mathrm{~kg}^{-1}$ of seed. The combination of Pseudomonas fluorescens and Trichoderma harzianum was applied in 50:50 ratio at the recommended dose of $8 \mathrm{~g}$ ( $4 \mathrm{~g}+4 \mathrm{~g}$ each) $\mathrm{kg}^{-1}$ of seed. Untreated seeds were considered as control. Seeds were then kept under warm and moist conditions at 28 ㅇ $\mathrm{C}$ for $24 \mathrm{~h}$ until prior to radical emergence.

\subsection{Field experiment}

In order to meet the requirement of the objectives, the field experiment was conducted at Research Station Gaja, College of Forestry, Ranichauri, Tehri Garhwal, Uttarakhand, India during kharif season 2014. The experiment was laid out in a factorial randomized block design with 3 replications. Row to row spacing of 45 centimeter and plant to plant spacing were kept 10 centimeter. The experiment was conducted to find out the influence of bio-agents on plant growth, seed yield and its contributing characters. The observations were recorded on nine characters namely field emergence, days to $50 \%$ flowering, plant height, no. of branches plant ${ }^{-1}$, no. of pods plant ${ }^{-1}$, pod length, no. of seeds pod ${ }^{-1}$, no. of nodules plant $^{-1}$ and seed yield plant ${ }^{-1}$.

\section{Results and Discussion}

\subsection{Effect of seed bio-priming on field emergence (\%)}

Maximum field emergence (88.47\%) was recorded with Psf173 bio-primed seeds followed by Pf+Th (82.43\%) and PSB $(74.98 \%)$ while, minimum mean field emergence was recorded in untreated (control) seeds (65.85\%).The data presented (Table 1) also exhibit that the variety had significant influence on field emergence. The maximum mean field emergence (89.27\%) was found in Shilajeet followed by PS 1092 (82.70\%) and minimum was noted for PRS1 (64.39\%). The interaction between treatments and varieties was found significant (Table 1). The combination of variety Shilajeet with bio-agent Psf-173 showed significant effect and had maximum field emergence (93.58\%) while, uninoculated seeds of PRS1 variety showed minimum field emergence (50.65\%).

Primed seed might have showed higher field emergence due to the production of microbial seed leachates that provide the source of carbon and nitrogen in the initial few days but there after the translocation of quantum and nature

Table 1: Effect of seed bio-priming on field emergence of soybean varieties

\begin{tabular}{|c|c|c|c|c|c|}
\hline \multirow{2}{*}{$\begin{array}{l}\text { Treat- } \\
\text { ments }\end{array}$} & \multicolumn{5}{|c|}{ Field emergence (\%) } \\
\hline & $\begin{array}{c}\text { Shila- } \\
\text { jeet }\left(\mathrm{V}_{1}\right)\end{array}$ & $\begin{array}{c}\text { PK } 327 \\
\left(V_{2}\right)\end{array}$ & $\begin{array}{c}\text { PS } 1092 \\
\left(V_{3}\right)\end{array}$ & $\begin{array}{c}\text { PRS1 } \\
\left(V_{4}\right) \\
\end{array}$ & Mean \\
\hline $\mathrm{T}_{1}$ & 88.42 & 67.99 & 82.76 & 60.77 & 74.98 \\
\hline $\mathrm{T}_{2}$ & 93.58 & 93.32 & 91.66 & 75.32 & 88.47 \\
\hline $\mathrm{T}_{3}$ & 90.14 & 56.36 & 87.66 & 63.55 & 74.42 \\
\hline $\mathrm{T}_{4}$ & 91.86 & 89.55 & 76.66 & 71.66 & 82.43 \\
\hline $\mathrm{T}_{5}$ & 82.32 & 55.66 & 74.76 & 50.65 & 65.85 \\
\hline \multirow[t]{2}{*}{ Mean } & 89.27 & 72.57 & 82.70 & 64.39 & 77.23 \\
\hline & Variety & \multicolumn{2}{|c|}{ Treatment } & \multicolumn{2}{|c|}{ Varietyxtreatment } \\
\hline SEm \pm & 0.437 & \multicolumn{2}{|c|}{0.489} & \multicolumn{2}{|c|}{0.978} \\
\hline $\begin{array}{l}C D \\
(p=0.05)\end{array}$ & 1.252 & \multicolumn{2}{|c|}{1.400} & \multicolumn{2}{|c|}{2.801} \\
\hline
\end{tabular}

$\mathrm{T}_{1}$ : PSB; $\mathrm{T}_{2}$ : Psf; $\mathrm{T}_{3}:$ Th; $\mathrm{T}_{4}$ : Psf-173+Th-14; $\mathrm{T}_{5}$ : Control

(qualitative and quantitative) of photosynthates in the form of root exudates would determine the proliferation of the microbial inoculants. In the present study, enhancement of seed germination and plant growth promotion in soybean might be due to production of growth regulators by Pf. This study is in close agreement with the results reported by Begum et al. (2010) in soybean, Reddy et al. (2011) in chickpea and Yadav et al. (2013) in chickpea and rajma. 


\subsection{Effect of seed bio-priming on days to $50 \%$ flowering}

Minimum number of days ( 40.75 days) required for $50 \%$ flowering was recorded with treatment Psf-173 followed by Psf-173+Th-14 (44.50 days) and PSB (45.33 days) whereas, maximum days to $50 \%$ flowering (47.66 days) was recorded in control. The varieties had significant influence on days to $50 \%$ flowering (Table 2). The earliest days to $50 \%$ flowering (39.13 days) was recorded in PS 1092 followed by PRS 1 (42.33 days) and Shilajeet ( 45.73 days) while, maximum days to $50 \%$ flowering (51.60 days) was observed in PK327 variety. The interaction effect of treatment and variety on days to $50 \%$ flowering was also found significant (Table 2). The earliest days to $50 \%$ flowering ( 37.33 days) was recorded in the combination of variety PS 1092 with Psf-173 whereas, maximum days taken to $50 \%$ flowering ( 56.33 days) was recorded in uninoculated PK327. These results are in agreement with those reported by Anitha et al. (2013) in soybean.

\subsection{Effect of seed bio-priming on plant height $(\mathrm{cm})$}

All the factors in experiment as well as their interactions showed significant influence on plant height. Maximum plant height $(30.34 \mathrm{~cm})$ was recorded with treatment Th-14 closely

Table 2: Effect of seed bio-priming on days to $50 \%$ flowering of soybean varieties

\begin{tabular}{lccccc}
\hline $\begin{array}{l}\text { Treat- } \\
\text { ments }\end{array}$ & \multicolumn{5}{c}{ Days to 50\% flowering (days) } \\
\cline { 2 - 6 } & $\begin{array}{c}\text { Shila- } \\
\text { jeet }\left(\mathrm{V}_{1}\right)\end{array}$ & $\begin{array}{c}\text { PK 327 } \\
\left(\mathrm{V}_{2}\right)\end{array}$ & $\begin{array}{c}\text { PS 1092 } \\
\left(\mathrm{V}_{3}\right)\end{array}$ & $\begin{array}{c}\text { PRS1 } \\
\left(\mathrm{V}_{4}\right)\end{array}$ & Mean \\
\hline $\mathrm{T}_{1}$ & 47.66 & 52.33 & 38.33 & 43.00 & 45.33 \\
$\mathrm{~T}_{2}$ & 42.33 & 43.66 & 37.33 & 39.66 & 40.75 \\
$\mathrm{~T}_{3}$ & 47.66 & 54.33 & 39.33 & 43.66 & 46.25 \\
$\mathrm{~T}_{4}$ & 47.33 & 51.33 & 38.33 & 41.00 & 44.50 \\
$\mathrm{~T}_{5}$ & 47.33 & 56.33 & 42.33 & 44.33 & 47.66 \\
Mean & 46.53 & 51.60 & 39.13 & 42.33 & 44.90 \\
& Variety & Treatment & Varietyxtreatment \\
SEm \pm & 0.317 & 0.354 & 0.708 \\
$\mathrm{CD}$ & 0.907 & 1.014 & & 2.029 \\
$(p=0.05)$ & \multicolumn{5}{c}{} \\
\hline
\end{tabular}

followed by Psf-173 $(30.13 \mathrm{~cm})$ and PSB $(29.76 \mathrm{~cm})$. However, minimum plant height was found in control $(28.84 \mathrm{~cm})$. Among different varieties, the highest plant height $(34.25 \mathrm{~cm})$ was recorded in Shilajeet variety followed by PS $1092(29.95 \mathrm{~cm})$ and the least plant height $(26.06 \mathrm{~cm})$ was recorded in PK 327 variety. Among the interaction, maximum plant height $(38.24 \mathrm{~cm})$ was found in the combination of variety Shilajeet with Psf-173 whereas minimum $(24.80 \mathrm{~cm})$ was recorded in combination of variety PK327 with PSB (Table 3). This increase in plant growth might be due to rhizobacterial action of auxin production and phosphate solubilization. Microbial auxin production and phosphate solubilization would have played a role in better plant growth including plant height. The elongation of plant height through microbial inoculants
Table 3: Effect of seed bio-priming on plant height of soybean varieties

\begin{tabular}{lccccc}
\hline $\begin{array}{l}\text { Treat- } \\
\text { ments }\end{array}$ & \multicolumn{5}{c}{ Plant hight (cm) } \\
\cline { 2 - 6 } & $\begin{array}{c}\text { Shila- } \\
\text { jeet }\left(\mathrm{V}_{1}\right)\end{array}$ & $\begin{array}{c}\text { PK 327 } \\
\left(\mathrm{V}_{2}\right)\end{array}$ & $\begin{array}{c}\text { PS 1092 } \\
\left(\mathrm{V}_{3}\right)\end{array}$ & $\begin{array}{c}\text { PRS1 } \\
\left(\mathrm{V}_{4}\right)\end{array}$ & Mean \\
\hline $\mathrm{T}_{1}$ & 36.94 & 24.80 & 30.88 & 26.44 & 29.76 \\
$\mathrm{~T}_{2}$ & 38.24 & 25.72 & 27.48 & 29.08 & 30.13 \\
$\mathrm{~T}_{3}$ & 35.52 & 26.66 & 30.70 & 28.48 & 30.34 \\
$\mathrm{~T}_{4}$ & 31.45 & 24.66 & 31.44 & 29.28 & 29.21 \\
$\mathrm{~T}_{5}$ & 29.09 & 28.48 & 29.26 & 28.54 & 28.84 \\
Mean & 34.25 & 26.06 & 29.95 & 28.36 & 29.65 \\
& Variety & Treatment & Variety×treatment \\
$\mathrm{SEm} \pm$ & 0.200 & 0.224 & & 0.448 \\
$\mathrm{CD}$ & 0.574 & 0.641 & & 1.283 \\
$(p=0.05)$ & \multicolumn{5}{c}{} \\
\hline
\end{tabular}

has already been reported by a number of workers. Similar findings in soybean have previously been reported by Yehia et al. (1994); Fath El-bab et al. (2013) in green bean.

\subsection{Effect of seed bio-priming on number of branches plant ${ }^{1}$}

Significantly maximum number of branches plant ${ }^{-1}$ were recorded on PSB (5.08) followed by Th-14 (4.30) where as minimum was recorded on Psf-173 (3.14). Among different varieties Shilajeet variety had significant influence on plant height and maximum number of branches were counted (4.46) while, minimum number of branches plant ${ }^{-1}$ for PRS 1 (3.34). Among different treatment and variety combinations the highest number of branches were counted in Shilajeet variety when bioprimed with PSB (5.62) and the least number of branches was recorded in combination of uninoculated PRS1 (2.86) (Table 4).

Table 4: Effect of seed bio-priming on number of branches plant $^{-1}$ of soybean varieties

\begin{tabular}{|c|c|c|c|c|c|}
\hline \multirow{2}{*}{$\begin{array}{l}\text { Treat- } \\
\text { ments }\end{array}$} & \multicolumn{5}{|c|}{ No. of branches plant ${ }^{-1}$} \\
\hline & $\begin{array}{c}\text { Shila- } \\
\text { jeet }\left(V_{1}\right)\end{array}$ & $\begin{array}{c}\text { PK } 327 \\
\left(V_{2}\right) \\
\end{array}$ & $\begin{array}{c}\text { PS } 1092 \\
\left(V_{3}\right) \\
\end{array}$ & $\begin{array}{l}\text { PRS1 } \\
\left(V_{4}\right)\end{array}$ & Mean \\
\hline $\mathrm{T}_{1}$ & 5.62 & 5.43 & 4.80 & 4.50 & 5.08 \\
\hline $\mathrm{T}_{2}$ & 4.33 & 3.62 & 3.86 & 3.20 & 3.75 \\
\hline $\mathrm{T}_{3}$ & 3.56 & 3.45 & 3.80 & 2.95 & 3.44 \\
\hline $\mathrm{T}_{4}$ & 5.46 & 4.50 & 4.05 & 3.20 & 4.30 \\
\hline $\mathrm{T}_{5}$ & 3.33 & 3.06 & 3.09 & 2.86 & 3.08 \\
\hline \multirow[t]{2}{*}{ Mean } & 4.46 & 4.01 & 3.92 & 3.34 & 3.93 \\
\hline & Variety & \multicolumn{2}{|c|}{ Treatment } & \multicolumn{2}{|c|}{ Variety $\times$ Treatment } \\
\hline SEm \pm & 0.193 & \multicolumn{2}{|c|}{0.216} & \multicolumn{2}{|c|}{0.432} \\
\hline $\begin{array}{l}C D \\
(p=0.05)\end{array}$ & 0.554 & \multicolumn{2}{|c|}{0.619} & \multicolumn{2}{|c|}{0.123} \\
\hline
\end{tabular}


Number of branches might have increased due to the availability of phosphorous in soil and plant growth promoting substances produced by microbial inoculants. Similar results in soybean were also presented by Umale et al. (2002); Singh et al. ( 2010).

\subsection{Effect of seed bio-priming on number of pods plant ${ }^{-1}$}

The treatment had significant influence on the number of pods plant ${ }^{-1}$. The maximum number of pods plant ${ }^{-1}$ (28.98) was counted in PSB while minimum in control (17.17). Significant variation in different varieties for number of pods plant ${ }^{-1}$ was also noticed. The maximum no. of pods (31.18) were recorded in Shilajeet variety followed by PS 1092 (29.26), PK 327 (15.68). The least number of pods (15.29) were recorded in PRS 1 variety (Table 5).

Table 5: Effect of seed bio-priming on no. of pod plant ${ }^{-1}$ of soybean varieties

\begin{tabular}{|c|c|c|c|c|c|}
\hline \multirow{2}{*}{$\begin{array}{l}\text { Treat- } \\
\text { ments }\end{array}$} & \multicolumn{5}{|c|}{ No. of pod plant ${ }^{-1}$} \\
\hline & $\begin{array}{c}\text { Shila- } \\
\text { jeet }\left(\mathrm{V}_{1}\right)\end{array}$ & $\begin{array}{c}\text { PK } 327 \\
\left(V_{2}\right)\end{array}$ & $\begin{array}{c}\text { PS } 1092 \\
\left(V_{3}\right)\end{array}$ & $\begin{array}{c}\text { PRS1 } \\
\left(V_{4}\right)\end{array}$ & Mean \\
\hline $\mathrm{T}_{1}$ & 36.46 & 20.65 & 35.20 & 23.61 & 28.98 \\
\hline $\mathrm{T}_{2}$ & 31.06 & 14.87 & 32.13 & 14.17 & 23.05 \\
\hline $\mathrm{T}_{3}$ & 28.16 & 13.36 & 25.84 & 12.48 & 19.96 \\
\hline $\mathrm{T}_{4}$ & 33.90 & 19.03 & 32.40 & 15.11 & 25.11 \\
\hline $\mathrm{T}_{5}$ & 26.33 & 10.51 & 20.74 & 11.12 & 17.17 \\
\hline \multirow[t]{2}{*}{ Mean } & 31.18 & 15.68 & 29.26 & 15.29 & 22.85 \\
\hline & Variety & \multicolumn{2}{|c|}{ Treatment } & \multicolumn{2}{|c|}{ Variety $\times$ Treatment } \\
\hline SEm \pm & 0.192 & \multicolumn{2}{|c|}{0.214} & \multicolumn{2}{|c|}{0.429} \\
\hline $\begin{array}{l}\text { CD } \\
(p=0.05)\end{array}$ & 0.550 & \multicolumn{2}{|c|}{0.615} & \multicolumn{2}{|c|}{1.230} \\
\hline
\end{tabular}

The interaction of treatments and varieties were found significant for number of pods plant ${ }^{-1}$. The highest number of pods (36.46) was recorded in Shilajeet when bio-primed with bio-agent PSB and the minimum number of pods (10.51) were recorded in uninoculated PK 327 . The reason might be due to the solubilization of mineral phosphate and mineralization of other nutrients and also the production of hormones like indole acetic acid (IAA), gibberellic acid and cytokinin through microbial action. Similar type of finding has also been reported by Argaw (2012) in soybean, Elkoca et al. (2008) in chickpea, Nagar and Meena (2004) in cluster bean and Singh et al. (2011) in lentil.

\subsection{Effect of seed bio-priming on pod length $(\mathrm{cm})$}

Analysis of variance for pod length showed significant differences due to varieties, treatments and varietyxtreatment. The perusal of data presented in Table 6 reveals that the treatment had significant influence on the pod length. The maximum pod length $(4.09 \mathrm{~cm})$ was found in PSB followed by Psf-173+Th-14 $(3.30 \mathrm{~cm})$ and Psf-173 (3.09 cm) while, minimum $(2.68 \mathrm{~cm})$ was found in control. Significant variation
Table 6: Effect of seed bio-priming on pod length of soybean varieties

\begin{tabular}{|c|c|c|c|c|c|}
\hline \multirow{2}{*}{$\begin{array}{l}\text { Treat- } \\
\text { ments }\end{array}$} & \multicolumn{5}{|c|}{ Pod length $(\mathrm{cm})$} \\
\hline & $\begin{array}{c}\text { Shila- } \\
\text { jeet }\left(\mathrm{V}_{1}\right)\end{array}$ & $\begin{array}{c}\text { PK } 327 \\
\left(V_{2}\right)\end{array}$ & $\begin{array}{c}\text { PS } 1092 \\
\left(V_{3}\right)\end{array}$ & $\begin{array}{c}\text { PRS1 } \\
\left(V_{4}\right)\end{array}$ & Mean \\
\hline $\mathrm{T}_{1}$ & 4.15 & 4.12 & 4.13 & 3.97 & 4.09 \\
\hline $\mathrm{T}_{2}$ & 3.38 & 3.07 & 2.99 & 2.93 & 3.09 \\
\hline $\mathrm{T}_{3}$ & 3.17 & 2.83 & 2.85 & 2.80 & 2.91 \\
\hline $\mathrm{T}_{4}$ & 3.46 & 3.12 & 3.14 & 3.48 & 3.30 \\
\hline $\mathrm{T}_{5}$ & 2.79 & 2.69 & 2.73 & 2.53 & 2.68 \\
\hline \multirow[t]{2}{*}{ Mean } & 3.39 & 3.16 & 3.17 & 3.14 & 3.21 \\
\hline & Variety & \multicolumn{2}{|c|}{ Treatment } & \multicolumn{2}{|c|}{ Varietyxtreatment } \\
\hline SEm \pm & 0.180 & \multicolumn{2}{|c|}{0.202} & \multicolumn{2}{|c|}{0.404} \\
\hline $\begin{array}{l}C D \\
(p=0.05)\end{array}$ & 0.051 & \multicolumn{2}{|c|}{0.578} & \multicolumn{2}{|c|}{0.115} \\
\hline
\end{tabular}

for all varieties for pod length was also noticed. The maximum pod length $(3.39 \mathrm{~cm})$ was recorded in Shilajeet variety followed by PS $1092(3.17 \mathrm{~cm})$ and PK $327(3.16 \mathrm{~cm})$ while, minimum pod length $(3.14 \mathrm{~cm}$ ) was recorded in PRS 1 variety.

The interaction of treatment and variety was found to have significant effect on pod length. The maximum pod length $(4.15 \mathrm{~cm})$ was found in Shilajeet when bioprimed with bioagent PSB and the minimum pod length was recorded in uninoculated PRS $1(2.53 \mathrm{~cm})$. Plants obtained from seeds bio-primed with beneficial microbes resulted in bigger pod length. The enhancement of pod length might be due to plant growth hormones like cytokinin like molecules, e.g. zeatin, and gibberellin GA3 produced by incorporated microbes. The results related to increase in pod length can be related to earlier findings reported by Nagar and Meena (2004) in cluster bean.

\subsection{Effect of bio-priming on number of seeds pod ${ }^{-1}$}

Significantly maximum number of seeds pod $^{-1}$ (2.70) were recorded in PSB treated seeds which was at par with Psf173+Th-14 (2.55), Psf-173 (2.34) while, minimum was found in control (2.14). Significant variation in different varieties for number of seeds pod $^{-1}$ was also noticed (Table 7$)$. The maximum number of seeds pod ${ }^{-1}$ (2.71) were found in Shilajeet variety which was statistically at par with PS 1092 (2.51), PK 327 (2.32) whereas, minimum number of seeds pod $^{-1}$ (1.99) was recorded in PRS 1 . The interaction of treatment and variety was found significant for number of seeds pod $^{-1}$ The highest number of seeds (3.00) were recorded in Shilajeet and PS1092 when bio-primed with bio-agent PSB and the minimum number of seeds (1.80) were counted in PRS 1 bio-primed with Th-14 and uninoculated PRS 1. It is evident from the results that inoculation of beneficial microorganisms through seed priming significantly increased the number of seeds pod ${ }^{-1}$. This enhancement in number of seeds per 


\begin{tabular}{|c|c|c|c|c|c|}
\hline \multirow{2}{*}{$\begin{array}{l}\text { Treat- } \\
\text { ments }\end{array}$} & \multicolumn{5}{|c|}{ No. of seed pod ${ }^{-1}$} \\
\hline & $\begin{array}{c}\text { Shila- } \\
\text { jeet }\left(V_{1}\right)\end{array}$ & $\begin{array}{c}\text { PK } 327 \\
\left(V_{2}\right)\end{array}$ & $\begin{array}{c}\text { PS } 1092 \\
\left(V_{3}\right)\end{array}$ & $\begin{array}{c}\text { PRS1 } \\
\left(V_{4}\right)\end{array}$ & Mean \\
\hline $\mathrm{T}_{1}$ & 3.00 & 2.60 & 3.00 & 2.20 & 2.70 \\
\hline $\mathrm{T}_{2}$ & 2.59 & 2.40 & 2.39 & 1.99 & 2.34 \\
\hline $\mathrm{T}_{3}$ & 2.59 & 2.20 & 2.20 & 1.80 & 2.20 \\
\hline $\mathrm{T}_{4}$ & 2.80 & 2.40 & 2.80 & 2.20 & 2.55 \\
\hline $\mathrm{T}_{5}$ & 2.60 & 1.99 & 2.20 & 1.80 & 2.14 \\
\hline \multirow[t]{2}{*}{ Mean } & 2.71 & 2.32 & 2.51 & 1.99 & 2.38 \\
\hline & Variety & \multicolumn{2}{|c|}{ Treatment } & \multicolumn{2}{|c|}{ Varietyxtreatment } \\
\hline SEm \pm & 0.146 & \multicolumn{2}{|c|}{0.163} & \multicolumn{2}{|c|}{0.326} \\
\hline $\begin{array}{l}C D \\
(p=0.05)\end{array}$ & 0.418 & \multicolumn{2}{|c|}{0.467} & \multicolumn{2}{|c|}{0.934} \\
\hline
\end{tabular}

pod might be due to the phosphate solubilizing activities of microbial inoculants that resulted in more nutrient uptake and better plant growth. These results are in close agreement with those of Argaw (2012); Singh et al. (2010) in soybean and Singh et al. (2011) in lentil.

\subsection{Effect of seed bio-priming on no. of nodule plant ${ }^{-1}$}

Significantly maximum number of nodules plant ${ }^{-1}$ (33.09) was recorded in PSB bio-primed seeds followed by Psf-173+Th-14 (30.90), Pf-173 (25.20) while, minimum was recorded in control (19.55). Similarly significant variation was found among different varieties (Table 8). The Shilajeet variety was reported to have maximum number of nodules (30.68) followed by PS 1092 (26.24) whereas, minimum number of nodules (23.42) was found in PRS 1. The variety and treatment interactions were also found to have significant influence

\begin{tabular}{|c|c|c|c|c|c|}
\hline \multicolumn{6}{|c|}{$\begin{array}{l}\text { Table 8: Effect of seed bio-priming on no. of nodule plant }{ }^{-1} \\
\text { of soybean varieties }\end{array}$} \\
\hline \multirow{2}{*}{$\begin{array}{l}\text { Treat- } \\
\text { ments }\end{array}$} & \multicolumn{5}{|c|}{ No. of nodule plant ${ }^{-1}$} \\
\hline & $\begin{array}{c}\text { Shila- } \\
\text { jeet }\left(\mathrm{V}_{1}\right)\end{array}$ & $\begin{array}{l}\text { PK } 327 \\
\left(V_{2}\right)\end{array}$ & $\begin{array}{l}\text { PS } 1092 \\
\left(V_{3}\right)\end{array}$ & $\begin{array}{l}\text { PRS1 } \\
\left(V_{4}\right)\end{array}$ & Mean \\
\hline $\mathrm{T}_{1}$ & 38.79 & 30.59 & 34.20 & 28.80 & 33.09 \\
\hline $\mathrm{T}_{2}$ & 27.40 & 25.00 & 26.40 & 22.00 & 25.20 \\
\hline $\mathrm{T}_{3}$ & 25.80 & 20.60 & 20.59 & 21.34 & 22.08 \\
\hline $\mathrm{T}_{4}$ & 36.20 & 30.20 & 30.20 & 27.00 & 30.90 \\
\hline $\mathrm{T}_{5}$ & 25.20 & 15.20 & 19.80 & 18.00 & 19.55 \\
\hline \multirow[t]{2}{*}{ Mean } & 30.68 & 24.32 & 26.24 & 23.42 & 26.16 \\
\hline & Variety & \multicolumn{2}{|c|}{ Treatment } & \multicolumn{2}{|c|}{ VarietyxTreatmen } \\
\hline SEm \pm & 0.169 & \multicolumn{2}{|c|}{0.189} & \multicolumn{2}{|c|}{0.378} \\
\hline $\begin{array}{l}\mathrm{CD} \\
(p=0.05)\end{array}$ & 0.484 & \multicolumn{2}{|c|}{0.541} & \multicolumn{2}{|c|}{1.082} \\
\hline
\end{tabular}

on the number of nodules plant ${ }^{-1}$. The maximum number of nodules (38.79) was found when Shilajeet variety bio-primed with PSB however, minimum number of nodules (15.20) was recorded when PK 327 seeds were remain untreated.

Rhizosperic microorganism may not only influence the inoculated rhizobia adversely through saprophytic competition, but also help them surviving through synergism resulting in an increased nodulation ability and $\mathrm{N}_{2}$ fixing efficiency. PSB enhance the root length by providing the insoluble phosphorous from soil that increases the occupancy of number of nodules. Such type of findings were also reported by Sandeep et al. (2008), Singh et al. (2010) in soybean, Singh et al. (2011) in lentil and Linu et al. (2009) in cowpea.

\subsection{Effect of seed bio-priming on seed yield plant ${ }^{-1}$}

Significantly higher seed yield (14.89 g) was recorded in PSB bio-primed seed followed by Psf-173+Th-14 (13.31 g) and Pf-173 (12.32 g) whereas, minimum seed yield $(9.83 \mathrm{~g})$ was recorded in control (Table 9). Similarly, significant variation found among different varieties. The Shilajeet variety showed maximum seed yield (17.03 g) followed by PS 1092 (13.07 g) and PK $327(11.42 \mathrm{~g})$ whereas, minimum seed yield $(7.48 \mathrm{~g})$ was recorded in PRS 1. The variety and treatment interaction was also found to have significant influence on seed yield plant $^{-1}$. The highest seed yield $(20.24 \mathrm{~g})$ was found when Shilajeet was bio-primed with PSB. However, minimum (6.92 g) was found in uninoculated PRS 1.

The possible reason for increase in yield and its contributing character may be due to cumulative effect of phosphate solubilization, plant growth promotion, nodulation promotion and disease suppression activities. The coordinated expression of above said activities might have been responsible for enhancing plant growth and yield in soybean. These results are in agreement with those reported by Dubey (1997); Sandeep et al. (2008); Singh et al. (2010) in soybean.

Table 9: Effect of seed bio-priming on seed yield plant ${ }^{-1}(\mathrm{~g})$ of soybean varieties

\begin{tabular}{lccccc}
\hline $\begin{array}{l}\text { Treat- } \\
\text { ments }\end{array}$ & \multicolumn{5}{c}{ Seed yield plant ${ }^{-1}(\mathrm{~g})$} \\
\cline { 2 - 6 } & $\begin{array}{c}\text { Shila- } \\
\text { jeet }\left(\mathrm{V}_{1}\right)\end{array}$ & $\begin{array}{c}\text { PK 327 } \\
\left(\mathrm{V}_{2}\right)\end{array}$ & $\begin{array}{c}\text { PS 1092 } \\
\left(\mathrm{V}_{3}\right)\end{array}$ & $\begin{array}{c}\text { PRS1 } \\
\left(\mathrm{V}_{4}\right)\end{array}$ & Mean \\
\hline $\mathrm{T}_{1}$ & 20.24 & 14.27 & 16.38 & 8.70 & 14.89 \\
$\mathrm{~T}_{2}$ & 18.09 & 10.92 & 13.13 & 7.15 & 12.32 \\
$\mathrm{~T}_{3}$ & 14.80 & 9.88 & 11.83 & 7.08 & 10.89 \\
$\mathrm{~T}_{4}$ & 18.63 & 13.26 & 13.81 & 7.56 & 13.31 \\
$\mathrm{~T}_{5}$ & 13.39 & 8.80 & 10.21 & 6.92 & 9.83 \\
Mean & 17.03 & 11.42 & 13.07 & 7.48 & 12.25 \\
& Variety & Treatment & Variety×Treatment \\
$\mathrm{SEm} \pm$ & 0.780 & 0.872 & & 0.174 \\
$\mathrm{CD}$ & 0.223 & 0.249 & & 0.499 \\
$(p=0.05)$ & \multicolumn{5}{c}{} \\
\hline
\end{tabular}




\section{Conclusion}

Seed bio-priming enhances growth and yield parameters in soybean. It is therefore suggested that before sowing soybean seed should be treated with PSB and Psf-173 appropriate bio-agents. By using these bio-agents in soybean, farmers of mid-hills of Uttarakhand can increase their productivity by suppressing diseases in soybean. So with the help of biopriming with different bio-agents or microbial inoculants the plant growth, seed yield and quality of soybean crop can be improved.

\section{References}

Argaw, A., 2012. Evalution of Co-inoculation of Bradirhizobium japonicum and phosphate solubilizing Pseudomonas spp. effect on soybean [Glycine max (L.) Merril] in Assosaarea. Journal of Agricultural Science and Technology 4, 213-224.

Anitha, M., Madhusudhan, U.V., Punith, C.H., 2013. Effect of organic and inorganic seed priming on soybean germination and yield parameters. Biolife Journal 1, 223-230.

Begum, M.M., Meon, Sariah, Puteh, Adam, Ahmad, M., Adidin, Z., Rahman, M.A., Siddiqui, Y., 2010. Field performance of bioprimed seeds to suppress Colletotrichum truncatum causing damping off and seedling stand of soybean. Biological Control 53, 18-23.

Dubey, S.K., 1997. Efficacy of phosphate solubilizing microorganism and Bradyrhizobium japonicum on yield of soybean (Glycene max L.) in vertisol. Agricultural Science Digest 17, 47-49.

Elkoca, E., Kantar, F., Sahin, F., 2008. Influence of nitrogen fixing and phosphorus solubilizing bacteria on the nodulation, plant growth, and yield of chickpea. Journal of Plant Nutrition 31, 157-171.

Entesari, M., Sharifzadeh, F., Ahmadzadeh, M., Farhangfar, M., 2013. Seed biopriming with Trichoderma species and Pseudomonas fluorescens on growth parameter, enzyme activity and nutritional status of soybean. International Journal of Agronomy and Plant Production 4, 610-619.

Fath, El-bab, T.Sh., Riad, S.R., El-Mohamedy, 2013. Biopriming seed treatment for suppressive root rot soil borne pathogens and improvement growth and yield of green bean (Phaseulas vulgaris L.) in new cultivated lands. Journal of Applied Science and Research 9, 4378-4387.

Herridge, D.F., Peoples, M.B., Boddey, R.M., 2008. Global inputs of biological nitrogen fixation in agricultural systems. Plant Soil 311, 1-18.

Linu, M.S., Stephen, J., Jisha, M.S., 2009. Phosphate solubilizing Gluconacetobacter sp., Burkholderia sp. and their potential interaction with cowpea (Vigna unguiculata L. Walp.). International Journal of Agricultural Research 4, 79-87.

Nagar, K.C., Meena N.L., 2004. Effect of phosphorous, sulphur and phosphate solubilizing bacteria on yield components, yield and quality of clusterbean (Cyanopsis tetragonoloba L. Taub.). Legume Research 27, 27-31.

Raei, E., Sedgi, M., Sayed, Sharifi, R., 2008. Effect of Bradyrhizobium inoculation, application of nitrogen and weeding on growth and seed filling rate in soybean. Journal of Agricultural Technology 12, 81-91.

Rao, A.S., Reddy, K.S., 2010. Nutrient management in soybean. In: The soybean: Botany, production and uses (Ed: Singh G). CAB International 30.

Reddy, A.S.R., Madhavi, G.B., Reddy, K.G., Yellareddygari, S.K., Reddy, M.S., 2011. Effect of seed biopriming with Trichoderma viride and Pseudomonas fluorescens in chickpea (Cicer arietinum) in Andhra Pradesh. Plant growth-promoting rhizobacteria (PGPR) for sustainable agriculture, 324-429.

Sandeep, A.R., Joseph, S., Jisha, M.S., 2008. Yield and nutrient uptake of Soybean [Glycine max (L.) Merril] as influenced by phosphate solubilizing microorganisms. World Journal of Agricultural Sciences 4, 835-838.

Savazzini, F., Longa, C.M.O., Pertot, I., 2009. Impact of the biocontrol agent Trichoderma atroviride SC1 on soil microbial communities of a vineyard in northern Itlaly. Soil Biology and Biochemistry 41, 1457-1465.

Singh, A.V., Prasad, B., Shah, S., 2010. Effect of phosphate solubilizing bacteria on plant growth promotion and nodulation in soybean [Glycine $\max (\mathrm{L}$.) Merril]. Journal of Hill Agriculture 1, 35-39.

Singh, A.V., Prasad, B., Shah, S., 2011. Influence of phosphate solubilizing bacteria for enhancement of plant growth and seed yield in lentil. Journal of Crop and Weed 7, 1-4.

Umale, S.M., Thosar, V.R., Chorey, A.B., Chimote, A.N., 2002. Growth response of soybean to Phosphorous solubilizing bacteria and phosphorous levels. Journal of Soil and Crops 12, 258-261.

Yadav, S.K., Dave, A., Sarkar, A., Singh, H.B., Sarma, B.K., 2013. Co-inoculate biopriming with Trichoderma, Pseudomonas and Rhizobium improves crop growth in Cicer arietinum and Phaseolus vulgaris. International Journal of Agriculture Environment and Biotechnology 6, 255-259.

Yehia, A.H., Abd-El.Kader, D.A., Salem, D.E., Sayad-Ahmed, A.A., 1994. Biological soil treatment with Trichoderma harzianum to control brown stem rot of soybean in Egypt. Egyptian Journal of Phytopatology 22, 143-157. 